\title{
Storage stability of sourdough bread with lactic acid bacteria culture solution and cinnamon extract
}

\author{
Chang Ki Huh ${ }^{1}$, Ki Hoon Shim ${ }^{2 *}$ \\ ${ }^{1}$ Department of Food Science and Technology, Sunchon National University, Suncheon 57922, Korea \\ ${ }^{2}$ Department of Food and Cooking Science, Sunchon National University, Suncheon 57922, Korea
}

\section{유산균 배양액과 계피추출물을 첨가한 sourdough bread의 저장 중 품질변화}

\author{
허창기 ${ }^{1} \cdot$ 심기훈 $^{2 *}$ \\ ${ }^{1}$ 순천대학교 생명산업과학대학 식품공학과, ${ }^{2}$ 순천대학교 생명산업과학대학 조리과학과
}

\begin{abstract}
This study investigated the changes in moisture content, $\mathrm{pH}$, titrated acidity, Hunter's color value, textural properties, and retarding retrogradation during the storage of sourdough bread made with lactic acid bacteria culture (LCBC) and cinnamon extract. The measurement results showed that the moisture content and $\mathrm{pH}$ of all the samples tended to decrease during the storage period; the CEO sample exhibited the least variation in moisture content, whereas the CE100 sample showed the least variation in $\mathrm{pH}$. The titrated acidity of all the samples increased during storage, but the extent decreased with the amount of cinnamon extract added. During the storage period, the redness, hardness, and gumminess increased; the whiteness, adhesiveness, springiness, and cohesiveness decreased; and the chewiness decreased after an initial increase. The retarding retrogradation was stronger for the group with LCBC and cinnamon extract, compared to that of the control, whereas the CE50 sample presented the strongest retarding retrogradation effect with the lowest Avrami exponent. These results suggested that the addition of LCBC and cinnamon extract during the manufacture of sourdough bread improved the storage period efficiency and retarding retrogradation.
\end{abstract}

Key words : lactic acid bacterial, cinnamon extract, sourdough bread, retrogradation

\section{서 론}

제빵 산업에서 상업용 효모가 사용되는 19세기 전까지는 sourdough starter를 이용한 발효법을 사용하였고, sourdough 를 이용한 제빵은 전통적으로 호밀을 이용하였으며, 발효 과정에서 반죽의 $\mathrm{pH}$ 가 낮아짐에 따라 내인성 아밀라아제 의 활성이 감소하여 반죽의 탄력성과 신장성을 높이고 빵의 부피를 증가시키면서 호밀빵 특유의 맛과 향미를 제공할 수 있었지만 sourdough bread의 기술적인 문제점들이 나타 나 sourdough를 이용한 제빵 제조가 기피되었다(1-3).

*Corresponding author. E-mail : khshim@sunchon.ac.kr Phone : 82-61-750-3697, Fax : 82-61-750-3690

Received 7 August 2018; Revised 28 September 2018; Accepted 5 November 2018.

Copyright (c) The Korean Society of Food Preservation. All rights reserved.
최근 들어 빵의 소비가 증가하면서 다양한 천연재료를 활용한 제품들이 개발되고 있고(4), 좀 더 자연적이고 건강 한 식품에 대한 소비자의 수요가 증가함에 따라 sourdough 를 이용한 전통적인 방법으로 빵을 만드는 것이 최근 몇 년간 발전하여 빵, 케이크 및 크래커와 같은 제품들이 나타 나기 시작했다(5-7). Sourdough bread는 일반적으로 젖산균 이나 효모를 사용하여 발효시키는 방법으로 많은 시간과 노력이 필요하지만 젖산균과 효모의 상호 작용 등에 의해서 나타나는 독특한 맛과 풍미를 즐기는 소비자가 늘어나면서 관련 제품을 판매하는 매장도 증가하고 있다(8).

Sourdough를 이용하여 빵을 제조하면 발효, 산성화, 반죽 특성 및 구조 개선을 포함하여 빵의 맛, 질감, 유해 곰팡이의 생육 억제 및 노화지연, 곡물의 영양 가용성 향상 그리고 저장 기간의 연장 등의 다양한 효과가 있는 것으로 알려져 있고, 이러한 효과는 젖산균과 효모균이 sourdough에서 자 연적으로 발생하는 것으로 알려져 있다(3,5,8-10) 
품질 개선을 목적으로 sourdough를 사용하는 것은 복잡 한 작업으로 sourdough를 사용하여 빵을 만들었을 때 Armero와 Collar(11), Rouzaud 등(12)의 연구에서는 부피와 저장 기간이 감소하는 것으로 나타났으나 Crowley 등(13) 의 연구에서는 증가하는 것으로 보고되어 sourdough를 사 용하는 것은 빵의 풍미를 바람직하게 또는 바람직하지 않게 할 수 있다(14,15). 이러한 sourdough bread의 품질 안정성이 불안정하여 제빵 산업에서 sourdough를 이용한 제품 생산 및 판매 등이 이루어지지 않는 것으로 생각된다.

Sourdough를 이용하여 빵을 제조하면 맛, 부피 및 저장기 간을 연장시킬 수 있지만 약간의 신맛이 있기 때문에 빵의 품질을 향상시키기 위한 조치가 필요하다(15). 전통적인 방법에서는 최종 제품의 신맛을 줄이기 위해서 sourdough 를 제한적으로 사용하여 왔지만 이러한 방법은 sourdough 만의 독특한 맛을 제한하는 방법으로 최근에는 산을 조절하 는 방법이나 아미노산과 휘발성 화합물을 결합시켜 사용하 는 방법도 개발되었다 $(16,17)$. 그러나 아직까지 sourdough 를 이용하여 빵의 부피와 저장성 향상을 유지하면서 특유의 신맛을 줄이기 위한 연구는 부족한 형편이다. 국내 연구에 서도 무화과 액종(1), 사과전립분(8), 오미자청(18), 오미자 발효액(19), 단감 발효종(20), 카무트 사워종(21), 이상발효 유산균과 내산성 효모(22), 깍두기로부터 분리된 유산균 (23) 등 다양한 첨가물과 유산균을 이용한 sourdough 식빵 의 품질특성 연구가 있었지만 특유의 신맛을 줄이면서 저장 성을 높이고, 천연 식품 재료 첨가에 따른 식빵의 품질을 유지하는 연구는 미흡하다.

계피는 수세기 동안 여러 문화권에서 향신료와 전통적인 약제로서 사용되어 왔으며 여러 국가의 식품과 제약 관련 산업에서 많은 용도로 활용되고 있다(24). 역사적으로 계피 의 의학적 사용과 음식에서의 사용을 구분하기 어렵지만 현재 계피가 항생제, 항산화제, 항암, 심혈관계 질환 및 면역 결핍증 등에서 건강에 도움이 되는 것으로 알려져 있다 (25-27).

따라서 본 연구에서는 sourdough 이용할 때 젖산균에 의해서 신맛을 완화시키면서 항균성이 있어 저장기간을 연장시킬 수 있는 계피 추출물과 식빵의 품질을 유지할 수 있도록 분리 동정한 젖산균의 첨가량을 달리한 sourdough bread를 제조하였고, $5^{\circ} \mathrm{C}$ 및 $20^{\circ} \mathrm{C}$ incubator에서 5 일간 저장하면서 수분함량, $\mathrm{pH}$, 적정산도, 색도, 물성 그리 고 노화도의 변화를 측정하여 저장성 향상과 노화 지연 효과를 살펴보았다.

\section{재료 및 방법}

재 료

본 실험에서 사용한 유산균 배양액은 김치로부터 분리한
것으로 최초 44종 유산균 중에서 항진균 활성이 크다고 판단된 22종 유산균을 선발하였으며, 임실지역 김치로부터 분리한 유산균을 Lactobacillus sakei subsp.로 동정한 $\mathrm{ALH}(L$ sakei subsp. ALI033)이 항진균 활성이 가장 큰 것으 로 평가되어 MRS 액체배지(Lactobacilli MRS broth, Difco, Franklin Lakes, NJ, USA)에 $\mathrm{ALH}$ 를 $2 \%(\mathrm{v} / \mathrm{v})$ 접종하여 $37^{\circ} \mathrm{C}$ 에서 48 시간 배양한 후 원심분리 $\left(3,000 \mathrm{rpm}, 10 \mathrm{~min}, 4^{\circ} \mathrm{C}\right)$ 하 여 사용하였다 $(28,29)$. 시판되고 있는 정유(essential oil)인 바질유, 송엽유, 박하유, 스페어민트유, 계피유, 생강유 및 레몬유의 항진균 활성을 분리 곰팡이를 이용하여 측정한 결과 계피유가 활성이 가장 좋은 것으로 나타나 본 실험에 서는 $10 \%(\mathrm{w} / \mathrm{v})$ 계피가루를 에탄올에 24 시간 침지한 후 원 심분리(10,000 rpm, $\left.10 \mathrm{~min}, 4^{\circ} \mathrm{C}\right)$ 하여 사용하였다(30). 식빵 재료로 강력분 밀가루(Daehan flour mills Co., Seoul, Korea), 쇼트닝(Samuang Co., Seoul, Korea), 이스트(Jenico Foods Co., Seoul, Korea), 설탕(Samyang Co., Seoul, Korea), 소금 (Dongwon Co., Seoul, Korea) 및 탈지분유(Seoul Milk Co., Seoul, Korea)는 시중에서 구입하여 사용하였다.

\section{유산균 배양액과 계피추출물을 첨가한 식빵 제조}

유산균 배양액과 계피추출물을 첨가한 식빵은 직접반죽 법으로 Table 1 과 같이 제조하였다(31). 강력분은 $1,200 \mathrm{~g}$, 물은 $700 \mathrm{~mL}$ 를 기본으로 하고 유산균 배양액과 계피추출물 을 첨가하지 않고 제조한 식빵을 대조구로 하였고, CEO 시료는 유산균 배양액만 $30 \mathrm{~g}, \mathrm{CE} 25$ 시료는 유산균 배양액 $22.5 \mathrm{~g}$ 과 계피추출물 $7.5 \mathrm{~g}, \mathrm{CE} 50$ 시료는 유산균 배양액 $15 \mathrm{~g}$ 과 계피추출물 $15 \mathrm{~g}, \mathrm{CE} 75$ 시료는 유산균 배양액 7.5 $\mathrm{g}$ 과 계피추출물 $22.5 \mathrm{~g}$ 그리고 CE100 시료는 계피추출물만 $30 \mathrm{~g}$ 첨가하였다. 이외에 쇼트닝 $36 \mathrm{~g}$, 설탕 $72 \mathrm{~g}$, 소금 $18 \mathrm{~g}$, 탈지분유 $48 \mathrm{~g}$, 이스트 $60 \mathrm{~g}$ 을 첨가하여 사용하였다. 반죽은 저속에서 2 분 동안 수화 후 쇼트닝을 첨가하여 중속 5 분, 고속 5 분으로 하였다. 1 차 발효는 습도 $75 \%$, 온도 $27^{\circ} \mathrm{C}$ 에서 40 분간 1 차 발효를 한 후 $180 \mathrm{~g}$ 씩 분할하여 15 분 동안 중간 발효를 하였다. 2 차 발효는 온도 $38^{\circ} \mathrm{C}$, 습도 $85 \%$ 에서 시행하였고, 윗불 $200^{\circ} \mathrm{C}$, 아랫불 $180^{\circ} \mathrm{C}$ 오븐에서 30 분간 구웠다.

\section{저장 중 식빵의 수분함량}

유산균 배양액과 계피추출물을 첨가한 식빵의 저장 중 수분함량은 온도 $20^{\circ} \mathrm{C}$ 의 incubator에서 $0,1,2,3,4$, 및 5 일 동안 저장하면서 경시적으로 시료를 채취하여 상압가열건 조법(32)으로 측정하였다.

\section{저장 중 식빵의 $\mathrm{pH}$}

유산균 배양액과 계피추출물을 첨가한 식빵의 저장 중 $\mathrm{pH}$ 는 온도 $20^{\circ} \mathrm{C}$ 의 incubator에서 $0,1,2,3,4$, 및 5 일 동안 저장하면서 경시적으로 시료를 $3 \mathrm{~g}$ 채취하여 증류수를 10 
Table 1. Formula of loaf bread with lactic acid bacteria cultured and cinnamon extract

\begin{tabular}{|c|c|c|c|c|c|c|}
\hline Samples ${ }^{1)}$ & Control & CE0 & CE25 & CE50 & CE75 & CE100 \\
\hline Wheat flour (g) & 1,200 & 1,200 & 1,200 & 1,200 & 1,200 & 1,200 \\
\hline Shortening (g) & 36 & 36 & 36 & 36 & 36 & 36 \\
\hline Sugar $(\mathrm{g})$ & 72 & 72 & 72 & 72 & 72 & 72 \\
\hline Salt (g) & 18 & 18 & 18 & 18 & 18 & 18 \\
\hline $\begin{array}{l}\text { Nonfat dry milk } \\
\text { powder }(\mathrm{g})\end{array}$ & 48 & 48 & 48 & 48 & 48 & 48 \\
\hline Yeast (g) & 60 & 60 & 60 & 60 & 60 & 60 \\
\hline Water $(\mathrm{mL})$ & 700 & 670 & 670 & 670 & 670 & 670 \\
\hline Lactic acid bacteria culture (g) & 0 & 30 & 22.5 & 15 & 7.5 & 0 \\
\hline Cinnamon extract (g) & 0 & 0 & 7.5 & 15 & 22.5 & 30 \\
\hline
\end{tabular}

${ }^{1)}$ Control, water $700 \mathrm{~g}$; CE0, water $670 \mathrm{~g}+$ lactic acid bacteria cultured $30 \mathrm{~g}$; CE25, water $670 \mathrm{~g}+$ lactic acid bacteria cultured $22.5 \mathrm{~g}+$ cinnamon extract $7.5 \mathrm{~g}$; CE50, water 670 g+lactic acid bacteria cultured $15 \mathrm{~g}+$ cinnamon extract $15 \mathrm{~g}$; CE75, water $670 \mathrm{~g}$ +lactic acid bacteria cultured $7.5 \mathrm{~g}+$ cinnamon extract $22.5 \mathrm{~g}$; CE100, water $670 \mathrm{~g}+\mathrm{cinnamon}$ extract $30 \mathrm{~g}$.

배 넣고 교반한 다음 $\mathrm{pH}$ meter(Accument $925 \mathrm{pH} / \mathrm{ion}$ meter, Fisher Scientific, Lenexa, KS, USA)로 측정하였다.

\section{저장 중 식빵의 적정산도}

유산균 배양액과 계피추출물을 첨가한 식빵의 저장 중 적정산도는 온도 $20^{\circ} \mathrm{C}$ 의 incubator에서 $0,1,2,3,4$, 및 5 일 동안 저장하면서 경시적으로 시료 $10 \mathrm{~g}$ 을 채취하여 증류수 를 10 배 넣고 실온에서 30 분간 교반한 다음, $1.81 \times 10^{3} \mathrm{~g}$ 에서 30 분간 원심분리(MF 600, Hanil Science Industrial, Gimpo, Korea)하여 상등액을 $0.1 \mathrm{~N} \mathrm{NaOH}$ 로 중화 적정하였다. 산도 는 소요된 $\mathrm{NaOH}$ 의 양으로 다음 계산식에 따라 lactic $\operatorname{acid}(\mathrm{mg} / 100 \mathrm{~g})$ 로 표시하였다.

$$
\text { 적정산도 }(\mathrm{mg} \%)=\frac{\mathrm{V} \times \mathrm{F} \times \mathrm{D} \times 0.009}{\mathrm{~S}} \times 100
$$

$\mathrm{V}: 0.01 \mathrm{~N} \mathrm{NaOH}$ 용액의 적정소비량 $(\mathrm{mL})$

$\mathrm{F}$ : $0.01 \mathrm{~N} \mathrm{NaOH}$ 용액의 역가

$\mathrm{D}$ : 희석배수

0.009 : lactic acid 계수 값

$\mathrm{S}$ : 시료채취량

\section{저장 중 식빵의 색도}

유산균 배양액과 계피추출물을 첨가한 식빵의 저장 중 색도는 온도 $20^{\circ} \mathrm{C}$ 의 incubator에서 $0,1,2,3,4$, 및 5 일 동안 저장하면서 경시적으로 시료를 채취하여 색차계(JC 801S, Tokyo, Japan)를 사용하여 $\mathrm{L}$ (백색도), $\mathrm{a}$ (적색도), $\mathrm{b}$ (황색도) 값을 측정하였다.

\section{저장 중 식빵의 물성}

유산균 배양액과 계피추출물을 첨가한 식빵의 저장 중
물성은 온도 $5^{\circ} \mathrm{C}$ 의 incubator에서 $0,1,2,3,4$, 및 5 일 동안 저장하면서 경시적으로 시료를 채취하여 빵 중심 부위를 $2 \times 2 \times 1 \mathrm{~cm}$ 로 절단하여 texture analyzer(TA-XT2i, Stable Micro System Co., Surrey, UK)를 이용하여 TPA(texture profile analysis)로 측정하였다. Compression force의 측정조 건은 test type: measure force compression, test speed: 0.1 $\mathrm{mm} / \mathrm{sec}$, strain: $50 \%$, probe: $\mathrm{P} / 45$ 으로 하였다. 위의 측정 후 얻어진 force-distance curve로부터 경도(hardness), 탄력 성(springiness), 응집성(cohesiveness), 점착성(gumminess), 씹힘성(chewiness)의 평균값을 구하였다.

\section{저장 중 식빵의 반응속도록적 노화도}

유산균 배양액과 계피추출물을 첨가한 식빵의 조직감 특성 중 경도 변화를 Avrami 방정식(34)에 적용하여 노화 특성을 분석하였다.

경도의 변화로

$$
\theta=e^{-k t^{n}}
$$

$\theta$ : 일정시간 후 결정화 되지 않은 부분

$k$ : 속도상수(rate constant)

$n$ : 결정화 mode에 따라 $1-4$ 의 값을 갖는 Avrami 지수

$t:$ 저장시간

$$
\frac{E_{L}-E_{t}}{E_{L}-E_{0}}=e^{-k t^{n}}
$$

$E_{0}$ : 초기(0시간)의 경도

$E_{t}: t$ 시간 경과 후의 경도

$E_{L}$ : 이론적으로 도달할 수 있는 최고의 경도 
식빵의 이론적 최고 경도(limiting modulus)는 $5^{\circ} \mathrm{C}$ 에서 5 일간 저장 후 경도를 얻었다.

식 (B)에서 자연로그와 사용로그를 취하면 다음과 같다.

$$
\begin{aligned}
& \ln \left(E_{L}-E_{t}\right) /\left(E_{L}-E_{0}\right)=-k t^{n} \\
& \log \left\{-\ln \left(E_{L}-E_{t}\right) /\left(E_{L}-E_{0}\right)\right\}=\log k+n \log t
\end{aligned}
$$

Avrami 지수(n)는 $\log$ 로 표식된 식 (D)에서 $\log$ $\left\{\left(E_{L}-E_{t}\right) /\left(E_{L}-E_{0}\right)\right\}$ (y축)을 $\log \mathrm{t}(\mathrm{x}$ 축 $)$ 에 대하여 좌표 로 나타낸 그래프의 기울기로 구하였다.

식 (B)에서 자연로그를 취하면 다음과 같다.

$$
\ln \left(E_{L}-E_{t}\right)=-k t^{n}+\ln \left(E_{L}-E_{0}\right)
$$

속도상수(k)는 방정식 $(\mathrm{E})$ 로부터 $\ln \left(E_{L}-E_{t}\right)$ 와 시간 $\mathrm{t}$ 를 축으로 한 그래프의 기울기로 구하였다.

\section{통계처리 방법}

실험결과는 SPSS 프로그램(IBM SPSS Sataistics 25, Armonk, NY, USA)을 이용하여 일원배치 분산분석 (ANOVA)으로 통계처리 하였으며, $\mathrm{p}<0.05$ 수준에서 Duncan's multiple range test를 실시하여 시료간의 유의적인 차이를 검증하였다.

\section{결과 및 고찰}

\section{저장 중 식빵의 수분함량, $\mathrm{pH}$, 적정산도 변화}

유산균 배양액과 계피추출물을 물 대신 첨가하여 제조한 식빵을 $20^{\circ} \mathrm{C}$ incubator에서 5 일 동안 저장하면서 수분함량, $\mathrm{pH}$ 및 적정산도의 변화를 측정한 결과는 Table 1 과 같다. 유산균 배양액만을 첨가한 $\mathrm{CE} 0$ 시료에서 가장 높았고, 계 피추출물만을 첨가한 CE100 시료에서 가장 낮았으며 시료 간에 유의한 차이가 있었다. 저장기간이 길어질수록 모든 시료에서 수분함량은 낮아지는 것으로 나타났고, 유산균 배양액만을 첨가한 $\mathrm{CE} 0$ 시료의 수분함량 감소가 가장 적은 것으로 나타났고, 유산균 배양액과 계피추출물을 $25: 75$ 의 비율로 첨가한 CE75 시료의 수분함량 감소가 가장 큰 것으 로 나타났으며, 저장기간에 따른 시료간에 유의한 차이가 있는 것으로 나타났다. Torrieri 등(34)의 연구는 밀가루에 sourdough를 첨가하여 제조한 식빵을 $4{ }^{\circ} \mathrm{C}$ 에서 15 일 동안 저장하면서 수분함량을 측정한 것으로 저장기간이 길어질 수록 수분함량이 감소하는 경향을 보였고 유의한 차이가 있는 것으로 나타났다. 또한 $\operatorname{Kim}(8)$ 의 연구에서도 저장기 간이 길어질수록 식빵의 수분함량이 줄어드는 경향으로
본 연구결과와 유사한 것으로 나타났다. 식빵의 수분함량 이 줄어드는 것은 식빵 내부의 수분이 환경적인 요인에 의해서 밖으로 확산되기 때문이고, 수분함량이 감소함에 따라 단단해지고 전분과 글루텐의 변형에 의해 노화가 진행 된다 $(35,36)$. 따라서 저장기간 동안 수분함량 감소를 최소 화하는 것이 노화의 진행을 늦추는 것으로 볼 수 있고, sourdough를 이용하여 식빵을 제조하는 방법은 저장기간 동안 수분함량을 유지하여 저장기간을 연장할 수 있는 방법 중 하나라고 생각된다.

$\mathrm{pH}$ 의 변화를 측정한 결과, 모든 시료가 각각의 저장기간 에서 첨가량에 따라 유의한 차이가 있었고, 각각의 시료는 저장기간에 따라서도 유의한 차이가 있는 것으로 나타났 다. 유산균 배양액 첨가량이 감소할수록 $\mathrm{pH}$ 는 감소하는 경향으로 나타났고, 저장기간이 길어질수록 계피추출물 첨 가량이 증가한 식빵의 $\mathrm{pH}$ 가 높아지는 것으로 나타났다. 저장기간 동안 $\mathrm{pH}$ 가 가장 적게 변화한 것은 $\mathrm{CE} 100$ 시료로 나타났고, 대조구가가 가장 크게 감소한 것으로 나타났으 며, 계피첨가량이 증가할수록 $\mathrm{pH}$ 감소 폭이 적은 것으로 나타났다. Aplevicz 등(36)의 연구에서도 반죽과 빵의 $\mathrm{pH}$ 값은 발효 시간이 길어지면서 감소하였고, 유기산에 의해 서 $\mathrm{pH}$ 값이 낮아지는 것은 sourdough의 점탄성에 영향을 미친다고 하였다. 무화과 액종(1)과 사과전립분 샤워종(8) 을 이용하여 sourdough bread의 품질 특성 연구에서 샤워종 과 액종 첨가량이 증가할수록 $\mathrm{pH}$ 는 낮아지는 것으로 나타 났고, 유의한 차이가 있는 것으로 나타나 본 연구와 유사한 결과를 보였다.

적정산도의 변화를 측정한 결과, 모든 시료가 저장기간 이 길어질수록 증가하는 경향을 보였고, 유산균 배양액 첨 가량이 감소하고 계피추출물 첨가량이 증가할수록 적정산 도의 증가 폭이 작게 나타났으며, 각각의 시료는 저장기간 에 따라 유의한 차이가 있는 것으로 나타났다. Torrieri 등 (34)의 연구와 Lappi 등(37)의 통밀을 이용한 식빵의 연구에 서도 대조구보다 sourdough를 이용한 식빵의 적정산도가 높았다. Bartkiene 등(38)의 연구에서도 sourdough 제조에 사용된 미생물에 의해서 식빵의 산도가 유의적으로 영향을 받는 것으로 나타났고, 모든 sourdough 식빵의 적정산도를 증가시키는 것으로 본 연구와 유사한 결과를 보였다. 저장 기간 동안 모든 시료의 적정산도는 증가하는 경향을 보였 고, 각각의 시료는 저장기간에 따라 유의한 차이가 있었다. 저장기간 동안 적정산도의 변화가 가장 큰 시료는 대조구로 나타났고, 계피추출물만을 첨가하여 제조한 식빵의 저장 중 적정산도의 변화가 가장 적은 것으로 나타났다. 유산균 배양액 첨가량이 감소하고 계피추출물 첨가량이 증가할수 록 저장기간 동안 적정산도의 변화가 적은 것으로 나타난 것은 Ryu 등(39)의 연구에서 계피추출물의 항균성이 저장 기간 동안 균의 생성을 억제하여 산 성분의 생성에 영향을 미친 것으로 생각된다. 계피추출물 첨가량이 증가할수록 
식빵의 총균수는 적었고, 곰팡이 균수를 측정한 결과에서 도 저장 3 일째부터 대조구와 유산균 배양액만을 첨가한 $\mathrm{CE} 0$ 시료에서 균수가 증가하였고, CE25, CE50 및 CE75는 저장 4일째부터 곰팡이가 발생하였고, $\mathrm{CE} 100$ 은 저장 5일째 부터 곰팡이가 발생하여 계피추출물 첨가량이 증가할수록 곰팡이 균수를 억제하는 것을 알 수 있었다.

\section{저장 중 식빵의 색도 변화}

유산균 배양액과 계피추출물을 물 대신 첨가하여 제조한 식빵을 $20^{\circ} \mathrm{C}$ incubator에서 5 일 동안 저장하면서 색도의 변화를 측정한 결과는 Table 2 와 같다. 백색도 측정 결과, 제조 당일부터 저장 5 일째까지는 대조구와 유산균 배양액 만을 첨가한 CE0 시료에서 가장 높았고, 계피추출물만을 첨가한 $\mathrm{CE} 100$ 시료에서 가장 낮았다. 저장기간 동안 유산 균 배양액만을 첨가한 CE0 시료에서 가장 변화가 컸고, 계피추출물만을 첨가한 CE100 시료가 가장 변화가 적었으 며, 각각의 시료와 저장기간에 따라 유의한 차이가 있는 것으로 나타났다. 적색도는 백색도와 반대로 저장기간이 길어질수록 모든 시료에서 증가하는 경향을 보였고, 저장 기간이 길어질수록 모든 시료에서 백색도는 감소하는 경향
을 보였다. 저장기간 동안 대조구의 백색도 변화가 가장 적었고, 유산균 배양액만을 첨가한 $\mathrm{CEO}$ 시료가 가장 변화 가 큰 것으로 나타났다. 황색도는 모든 시료가 저장 1 일째 감소하는 경향을 보였지만 그 이후에는 시료와 저장기간에 따라 감소와 증가를 반복하는 불규칙한 경향을 보였으며, 각각의 시료와 저장기간에 따라 유의한 차이가 나타났다. Song 등(40)의 계피 분말을 첨가한 쿠키의 연구에서 계피 분말 첨가량이 증가할수록 백색도는 감소하였고, 적색도와 황색도는 증가하는 경향으로 유사한 결과를 보였다. 저장 기간 동안 백색도는 감소하는 경향을 보였고, 적색도는 증 가하는 경향을 보였으나 황색도는 감소하다가 다시 증가하 는 경향을 보였다. Park 등(41)의 도토리식빵에 관한 연구에 서는 저장기간이 경과함에 따라 백색도는 감소하였고, 적 색도와 황색도는 증가하여 다소 상이한 결과를 보였지만, Kang 등(42)의 우유식빵에 관한 연구에서는 저장기간이 경과함에 따라 색도는 다소 불규칙한 변화를 보여 본 연구 결과와 유사하였다.

\section{저장 중 식빵의 물성 변화}

유산균 배양액과 계피추출물을 물 대신 첨가하여 제조한

Table 2. Changes in moisture, $\mathrm{pH}$ and titratable acidity of loaf bread with lactic acid bacteria cultured and cinnamon extract

\begin{tabular}{|c|c|c|c|c|c|c|c|}
\hline \multirow{2}{*}{\multicolumn{2}{|c|}{ Samples ${ }^{1)}$}} & \multicolumn{6}{|c|}{ Storage time (days) } \\
\hline & & 0 & 1 & 2 & 3 & 4 & 5 \\
\hline \multirow{6}{*}{$\begin{array}{c}\text { Moisture } \\
(\%)\end{array}$} & Control & $40.15 \pm 0.28^{2(b 3) A 4)}$ & $37.51 \pm 0.43^{\mathrm{aB}}$ & $35.32 \pm 0.45^{\mathrm{aC}}$ & $34.14 \pm 0.24^{\mathrm{aD}}$ & $33.46 \pm 0.17^{\mathrm{aE}}$ & $32.49 \pm 0.22^{2 \mathrm{~F}}$ \\
\hline & CE0 & $40.74 \pm 0.23^{\mathrm{aA}}$ & $36.57 \pm 0.45^{\mathrm{bB}}$ & $35.66 \pm 0.43^{\mathrm{aC}}$ & $34.65 \pm 0.13^{\mathrm{aD}}$ & $34.45 \pm 0.60^{\mathrm{aD}}$ & $33.21 \pm 0.03^{\mathrm{aE}}$ \\
\hline & CE25 & $39.82 \pm 0.04^{\mathrm{bA}}$ & $36.49 \pm 0.19^{\mathrm{bB}}$ & $33.76 \pm 0.57^{\mathrm{bC}}$ & $32.29 \pm 0.60^{6 \mathrm{D}}$ & $29.85 \pm 0.75^{\mathrm{bE}}$ & $29.26 \pm 0.45^{\mathrm{bE}}$ \\
\hline & CE50 & $39.79 \pm 0.16^{\mathrm{bA}}$ & $35.60 \pm 0.47^{\mathrm{CB}}$ & $32.94 \pm 0.41^{\mathrm{bcC}}$ & $31.18 \pm 0.83^{\mathrm{CD}}$ & $28.75 \pm 0.68^{\mathrm{bE}}$ & $28.25 \pm 0.27^{6 \mathrm{E}}$ \\
\hline & CE75 & $38.88 \pm 0.16^{\mathrm{cA}}$ & $35.66 \pm 0.29^{\mathrm{CB}}$ & $32.18 \pm 0.88^{\mathrm{cdC}}$ & $29.52 \pm 0.78^{\mathrm{dD}}$ & $28.65 \pm 0.89^{\mathrm{bD}}$ & $28.14 \pm 1.04^{b D}$ \\
\hline & CE100 & $37.96 \pm 0.60^{\mathrm{dA}}$ & $35.60 \pm 0.48^{\mathrm{CB}}$ & $31.03 \pm 1.17^{\mathrm{dC}}$ & $29.29 \pm 0.08^{\mathrm{dD}}$ & $29.07 \pm 0.66^{\mathrm{bD}}$ & $28.75 \pm 1.07^{\mathrm{bD}}$ \\
\hline \multirow{6}{*}{$\mathrm{pH}$} & Control & $6.44 \pm 0.04^{\mathrm{cA}}$ & $6.23 \pm 0.03^{\mathrm{dB}}$ & $5.58 \pm 0.06^{\mathrm{aC}}$ & $5.19 \pm 0.05^{\mathrm{aD}}$ & $5.06 \pm 0.02^{\mathrm{cE}}$ & $4.64 \pm 0.02^{\mathrm{cF}}$ \\
\hline & CE0 & $6.58 \pm 0.01^{\mathrm{AA}}$ & $6.37 \pm 0.01^{\mathrm{B}}$ & $5.44 \pm 0.01^{\mathrm{bC}}$ & $5.20 \pm 0.01^{\mathrm{aD}}$ & $5.11 \pm 0.03^{\mathrm{bE}}$ & $4.90 \pm 0.02^{\mathrm{bF}}$ \\
\hline & CE25 & $6.47 \pm 0.01^{\mathrm{cA}}$ & $6.26 \pm 0.00^{\mathrm{CB}}$ & $5.47 \pm 0.01^{\mathrm{bC}}$ & $5.14 \pm 0.01^{\mathrm{bD}}$ & $5.02 \pm 0.01^{\mathbb{d E}}$ & $5.01 \pm 0.03^{\mathrm{aE}}$ \\
\hline & CE50 & $6.52 \pm 0.01^{\mathrm{bA}}$ & $6.31 \pm 0.01^{\mathrm{bB}}$ & $5.48 \pm 0.01^{\mathrm{bC}}$ & $5.17 \pm 0.02^{\mathrm{abD}}$ & $5.16 \pm 0.03^{\mathrm{aD}}$ & $5.00 \pm 0.06^{\mathrm{aE}}$ \\
\hline & CE75 & $6.50 \pm 0.00^{\mathrm{bA}}$ & $6.29 \pm 0.00^{\mathrm{bB}}$ & $5.46 \pm 0.03^{\mathrm{bC}}$ & $5.13 \pm 0.03^{\mathrm{bD}}$ & $5.13 \pm 0.02^{\mathrm{abD}}$ & $5.01 \pm 0.02^{\mathrm{aE}}$ \\
\hline & CE100 & $6.36 \pm 0.02^{\mathrm{dA}}$ & $6.14 \pm 0.01^{\mathrm{e}}$ & $5.35 \pm 0.02^{\mathrm{cC}}$ & $5.04 \pm 0.02^{\mathrm{CD}}$ & $5.04 \pm 0.01^{\mathrm{cdD}}$ & $5.03 \pm 0.03^{\mathrm{a}}$ \\
\hline \multirow{6}{*}{$\begin{array}{c}\text { Titratable } \\
\text { acidity } \\
(\mathrm{mg} \%)\end{array}$} & Control & $7.79 \pm 0.24^{\mathrm{D}}$ & $8.49 \pm 0.57^{\mathrm{cD}}$ & $8.54 \pm 0.19^{\mathrm{bD}}$ & $9.58 \pm 0.35^{\mathrm{C}}$ & $12.05 \pm 0.75^{\mathrm{aB}}$ & $13.30 \pm 0.17^{\mathrm{AA}}$ \\
\hline & CE0 & $7.66 \pm 0.16^{\mathrm{E}}$ & $8.63 \pm 0.29^{\mathrm{cD}}$ & $9.57 \pm 0.15^{\mathrm{aC}}$ & $9.57 \pm 0.15^{\mathrm{C}}$ & $11.44 \pm 0.52^{\mathrm{abB}}$ & $13.16 \pm 0.69^{\mathrm{aA}}$ \\
\hline & CE25 & $7.72 \pm 0.33^{\mathrm{D}}$ & $9.77 \pm 0.38^{\mathrm{aC}}$ & $10.23 \pm 0.84^{4 \mathrm{BC}}$ & $10.50 \pm 0.63^{\mathrm{BC}}$ & $11.28 \pm 0.74^{\mathrm{abB}}$ & $13.14 \pm 0.48^{\mathrm{aA}}$ \\
\hline & CE50 & $8.15 \pm 0.60^{\mathrm{E}}$ & $8.91 \pm 0.17^{\mathrm{bcD}}$ & $10.04 \pm 0.17^{\mathrm{aC}}$ & $10.19 \pm 0.19^{\mathrm{C}}$ & $11.57 \pm 0.43^{\mathrm{abB}}$ & $12.97 \pm 0.60^{\mathrm{aA}}$ \\
\hline & CE75 & $8.46 \pm 0.59^{\mathrm{D}}$ & $9.38 \pm 0.22^{\mathrm{abC}}$ & $9.53 \pm 0.34^{\mathrm{aC}}$ & $10.76 \pm 0.93^{\mathrm{B}}$ & $10.81 \pm 0.45^{\mathrm{abB}}$ & $12.77 \pm 0.18^{\mathrm{aA}}$ \\
\hline & CE100 & $8.55 \pm 0.38^{\mathrm{D}}$ & $9.31 \pm 0.27^{\mathrm{abCD}}$ & $10.07 \pm 0.33^{\mathrm{aBC}}$ & $10.63 \pm 0.54^{\mathrm{AB}}$ & $10.75 \pm 0.80^{\mathrm{bAB}}$ & $11.52 \pm 0.96^{b A}$ \\
\hline
\end{tabular}

${ }^{1)}$ Control, water $700 \mathrm{~g}$; CE0, water $670 \mathrm{~g}+$ lactic acid bacteria cultured $30 \mathrm{~g}$; CE25, water $670 \mathrm{~g}+$ lactic acid bacteria cultured $22.5 \mathrm{~g}+\mathrm{cinnamon}$ extract $7.5 \mathrm{~g}$; CE50, water $670 \mathrm{~g}+$ lactic acid bacteria cultured $15 \mathrm{~g}$-cinnamon extract $15 \mathrm{~g}$; CE75, water $670 \mathrm{~g}$-lactic acid bacteria cultured $7.5 \mathrm{~g}$-cinnamon extract $22.5 \mathrm{~g}$; CE100, water $670 \mathrm{~g}+$ cinnamon extract $30 \mathrm{~g}$.

${ }^{2)}$ All values are mean $\pm \mathrm{SD}$. Mean with different superscript within a column are significantly different $(\mathrm{p}<0.05)$ by Duncan's multiple range test.

3)a-e Means Duncan's multiple range test for different addition (column).

4)A-F Means Duncan's multiple range test for storage time (row). 
Table 3. Changes in Hunter's color value of loaf bread with lactic acid bacteria cultured and cinnamon extract

\begin{tabular}{|c|c|c|c|c|c|c|c|}
\hline \multirow{2}{*}{\multicolumn{2}{|c|}{ Samples ${ }^{1)}$}} & \multicolumn{6}{|c|}{ Storage time (days) } \\
\hline & & 0 & 1 & 2 & 3 & 4 & 5 \\
\hline \multirow{6}{*}{$\mathrm{L}$} & Control & $80.22 \pm 0.20^{2(2) 3) A 4)}$ & $78.70 \pm 0.68^{\mathrm{aB}}$ & $78.49 \pm 0.31^{\mathrm{aB}}$ & $77.59 \pm 0.84^{\mathrm{bC}}$ & $76.70 \pm 0.92^{\mathrm{bC}}$ & $73.19 \pm 1.14^{4 \mathrm{D}}$ \\
\hline & CE0 & $79.88 \pm 0.28^{\mathrm{aA}}$ & $79.11 \pm 0.21^{\mathrm{aB}}$ & $79.09 \pm 0.27^{\mathrm{aB}}$ & $78.53 \pm 0.68^{\mathrm{aB}}$ & $77.73 \pm 1.05^{\mathrm{aC}}$ & $70.74 \pm 0.74^{b D}$ \\
\hline & CE25 & $72.99 \pm 0.32^{\mathrm{bA}}$ & $71.91 \pm 1.18^{\mathrm{bAB}}$ & $71.90 \pm 0.51^{\mathrm{bBC}}$ & $71.54 \pm 0.48^{\mathrm{cBC}}$ & $72.41 \pm 0.66^{\mathrm{C}}$ & $68.40 \pm 0.22^{\mathrm{cD}}$ \\
\hline & CE50 & $68.89 \pm 0.38^{\mathrm{cA}}$ & $68.82 \pm 0.69^{\mathrm{cA}}$ & $68.09 \pm 0.92^{\mathrm{cAB}}$ & $67.69 \pm 0.69^{\mathrm{dB}}$ & $67.19 \pm 0.83^{\mathrm{dB}}$ & $65.52 \pm 0.76^{\mathrm{dC}}$ \\
\hline & CE75 & $65.04 \pm 0.41^{\mathrm{dA}}$ & $64.82 \pm 0.35^{\mathrm{dA}}$ & $64.35 \pm 2.02^{\mathrm{dA}}$ & $63.83 \pm 0.39^{\mathrm{eAB}}$ & $62.90 \pm 0.94^{\mathrm{eB}}$ & $58.40 \pm 0.33^{\mathrm{eC}}$ \\
\hline & CE100 & $58.32 \pm 0.70^{\mathrm{eA}}$ & $57.93 \pm 0.35^{\mathrm{eA}}$ & $57.90 \pm 0.20^{\mathrm{eA}}$ & $57.11 \pm 0.11^{\mathrm{fB}}$ & $57.11 \pm 0.53^{\mathrm{fB}}$ & $56.40 \pm 0.33^{\mathrm{fC}}$ \\
\hline \multirow{6}{*}{$\mathrm{a}$} & Control & $-1.77 \pm 0.32^{\mathrm{e}}$ & $-1.64 \pm 0.35^{\mathrm{e}}$ & $-1.53 \pm 0.53^{\mathrm{e}}$ & $-1.51 \pm 0.81^{\mathrm{e}}$ & $-1.49 \pm 0.51^{\mathrm{e}}$ & $-1.17 \pm 0.16^{f}$ \\
\hline & $\mathrm{CE} 0$ & $-1.91 \pm 0.70^{\mathrm{eC}}$ & $-1.83 \pm 0.29^{\mathrm{eC}}$ & $-1.75 \pm 0.27^{\mathrm{CC}}$ & $-1.64 \pm 0.22^{\mathrm{eC}}$ & $-1.10 \pm 0.32^{\mathrm{eB}}$ & $-0.31 \pm 0.14^{\mathrm{eA}}$ \\
\hline & CE25 & $2.04 \pm 0.23^{\mathrm{d}}$ & $2.05 \pm 0.29^{\mathrm{d}}$ & $2.29 \pm 0.24^{d}$ & $2.30 \pm 0.50^{\mathrm{d}}$ & $2.35 \pm 0.43^{\mathrm{d}}$ & $2.42 \pm 0.24^{\mathrm{d}}$ \\
\hline & CE50 & $2.91 \pm 0.81^{\mathrm{CD}}$ & $3.09 \pm 1.02^{\mathrm{cCD}}$ & $3.51 \pm 0.69^{\mathrm{CBCD}}$ & $3.74 \pm 0.36^{\mathrm{cABC}}$ & $4.00 \pm 0.29^{\mathrm{cAB}}$ & $4.41 \pm 0.17^{\mathrm{cA}}$ \\
\hline & CE75 & $3.98 \pm 0.67^{\mathrm{bC}}$ & $4.79 \pm 0.44^{\mathrm{bB}}$ & $4.82 \pm 0.62^{\mathrm{bB}}$ & $5.00 \pm 0.49^{\mathrm{bAB}}$ & $5.64 \pm 0.55^{\mathrm{bAB}}$ & $5.25 \pm 0.21^{\mathrm{bA}}$ \\
\hline & CE100 & $6.39 \pm 0.25^{\mathrm{aD}}$ & $7.28 \pm 0.22^{\mathrm{aC}}$ & $7.34 \pm 0.31^{\mathrm{aBC}}$ & $7.61 \pm 0.20^{\mathrm{aAB}}$ & $7.73 \pm 0.21^{\mathrm{aA}}$ & $7.86 \pm 0.18^{\mathrm{aA}}$ \\
\hline \multirow{6}{*}{$\mathrm{b}$} & Control & $20.55 \pm 0.35^{\mathrm{bA}}$ & $18.88 \pm 0.24^{\mathrm{eC}}$ & $19.09 \pm 0.30^{\mathrm{cdC}}$ & $19.06 \pm 0.33^{\mathrm{cC}}$ & $20.81 \pm 0.30^{\mathrm{bA}}$ & $19.56 \pm 0.18^{\mathrm{dB}}$ \\
\hline & CE0 & $19.88 \pm 0.19^{\mathrm{cA}}$ & $18.65 \pm 0.22^{\mathrm{eB}}$ & $18.93 \pm 0.26^{\mathrm{dB}}$ & $18.89 \pm 1.37^{\mathrm{CB}}$ & $19.89 \pm 0.42^{\mathrm{cA}}$ & $20.47 \pm 0.37^{\mathrm{cA}}$ \\
\hline & CE25 & $19.79 \pm 0.44^{\mathrm{CBC}}$ & $19.44 \pm 0.20^{\mathrm{dCD}}$ & $19.54 \pm 0.49^{\mathrm{bcc}}$ & $20.00 \pm 0.25^{\mathrm{bB}}$ & $19.03 \pm 0.38^{\mathrm{eB}}$ & $20.74 \pm 0.35^{\mathrm{cA}}$ \\
\hline & CE50 & $20.53 \pm 0.25^{\mathrm{bB}}$ & $19.87 \pm 0.37^{\mathrm{C}}$ & $19.72 \pm 0.11^{\mathrm{bC}}$ & $20.67 \pm 0.51^{\mathrm{bAB}}$ & $19.44 \pm 0.37^{\mathrm{dC}}$ & $21.19 \pm 0.84^{\mathrm{cA}}$ \\
\hline & CE75 & $20.85 \pm 0.18^{\mathrm{bB}}$ & $20.76 \pm 0.13^{\mathrm{bBC}}$ & $20.05 \pm 0.84^{\mathrm{bD}}$ & $20.55 \pm 0.28^{\mathrm{bBCD}}$ & $20.23 \pm 0.25^{\mathrm{CD}}$ & $22.61 \pm 0.51^{\mathrm{bA}}$ \\
\hline & CE100 & $23.80 \pm 0.03^{\mathrm{aA}}$ & $22.18 \pm 0.10^{\mathrm{aB}}$ & $21.91 \pm 0.32^{\mathrm{aB}}$ & $21.79 \pm 0.08^{\mathrm{aB}}$ & $22.09 \pm 0.14^{\mathrm{aB}}$ & $23.53 \pm 0.96^{\mathrm{aA}}$ \\
\hline
\end{tabular}

${ }^{11}$ Control, water $700 \mathrm{~g}$; CE0, water $670 \mathrm{~g}$ +lactic acid bacteria cultured $30 \mathrm{~g}$; CE25, water $670 \mathrm{~g}$ +lactic acid bacteria cultured $22.5 \mathrm{~g}+\mathrm{cinnamon}$ extract $7.5 \mathrm{~g}$; CE50, water $670 \mathrm{~g}+$ lactic acid bacteria cultured $15 \mathrm{~g}$-cinnamon extract $15 \mathrm{~g}$; CE75, water $670 \mathrm{~g}+$ lactic acid bacteria cultured $7.5 \mathrm{~g}+$ cinnamon extract $22.5 \mathrm{~g}$; CE100, water $670 \mathrm{~g}+$ cinnamon extract $30 \mathrm{~g}$.

${ }^{2)}$ All values are mean $\pm \mathrm{SD}$. Mean with different superscript within a column are significantly different $(\mathrm{p}<0.05)$ by Duncan's multiple range test.

${ }^{3) a-e}$ Means Duncan's multiple range test for different addition (column).

${ }^{4) A-D}$ Means Duncan's multiple range test for storage time (row)

식빵을 $5^{\circ} \mathrm{C}$ incubator에서 5 일 동안 저장하면서 물성의 변화 를 측정한 결과는 Table 4 와 같다. 경도는 저장기간 동안 계피추출물만을 첨가한 CE100 시료가 가장 높았고, 유산균 배양액만을 첨가한 CE0 시료가 가장 낮았다. 저장기간이 길어질수록 모든 시료의 경도는 증가하는 경향을 보였으 며, 각각의 시료와 저장기간에 따라 유의한 차이가 있었다. Fagundes 등(43)에 의하면 식빵의 경도는 식빵 표본의 변형 을 주는 힘과 관련이 있고, 경도의 차이는 식빵 제조시 첨가 되는 재료와 수분함량에 따라서 달라진다고 하였다. Katina 등(15)의 연구에서는 저장 1 일에는 대조구와 sourdough bread와 크게 차이가 있지는 않았지만 저장 4 일에 측정한 결과 대조구와 비교해서 sourdough bread의 경도가 100-190 $\mathrm{g}$ 감소하는 것으로 나타났다. 부착성, 탄력성 및 응집성은 저장기간이 길어질수록 모든 시료에서 감소하는 경향을 보였고, 탄력성과 응집성은 각각의 시료와 저장기간에 따 라 유의한 차이가 있었다. 계피추출물만을 첨가한 CE100 시료는 부착성에서 저장 2 일째부터 가장 낮았고, 탄력성과 응집성에서는 저장기간 동안 가장 낮은 것으로 나타났다. 유산균 배양액 첨가량이 높을수록 탄력성은 대조구보다
높은 것으로 나타나 유산균 배양액에 식빵의 탄력성에 긍정 적인 효과를 주는 것으로 생각된다. 점착성과 씹힘성은 각 각의 시료와 저장기간에 따라 유의적인 차이는 보였지만, 저장기간 동안 증가와 감소를 반복하는 불규칙한 경향을 보였다. 점착성과 씹힘성은 경도, 탄력성 및 응집성의 계산 에 의해서 나타나는 값으로 경도의 증가와 탄력성과 응집성 의 감소 폭의 차이에 의한 것으로 생각된다. Sourdough의 유산균과 효모 등의 미생물 대사적 상호작용에 의해 유산균 의 생화학적 및 생리학적 특성을 나타내며, sourdough bread 의 부피, 부서짐성 및 가공성 등의 물성에 영향을 미치는 것으로 알려져 있다(35).

\section{저장 중 식빵의 노화도 변화}

식빵의 경도는 노화를 측정하는데 사용되는데, 유산균 배양액과 계피추출물을 물 대신 첨가하여 제조한 식빵을 $5^{\circ} \mathrm{C}$ incubator에서 저장하면서 측정한 물성의 경도 값을 이 용하여 식빵의 노화를 측정하였다. 대조구와 유산균 배양 액 및 계피추출물을 첨가한 식빵의 Avrami 지수(n), 속도상 수 $(k)$ 그리고 시간상수 $(1 / k)$ 의 결과는 Table $5, \log \{-\ln$ $\left(E_{L}-E_{t}\right) /\left(E_{L}-E_{0}\right)$ 와 $\log t$ 를 축으로 나타낸 결과와 $\ln \left(E_{L}-E_{t}\right)$ 와 
Table 4. Changes in texture properties of loaf bread with lactic acid bacteria cultured and cinnamon extract

\begin{tabular}{|c|c|c|c|c|c|c|c|}
\hline \multirow{2}{*}{\multicolumn{2}{|c|}{ Samples ${ }^{1)}$}} & \multicolumn{6}{|c|}{ Storage time (days) } \\
\hline & & 0 & 1 & 2 & 3 & 4 & 5 \\
\hline \multirow{6}{*}{ Hardness } & Control & $5.54 \pm 0.81^{26 b 3)(D 4)}$ & $5.96 \pm 0.46^{\mathrm{cD}}$ & $8.10 \pm 0.68^{\mathrm{bC}}$ & $8.15 \pm 0.31^{\mathrm{cC}}$ & $8.84 \pm 0.72^{\mathrm{cB}}$ & $10.30 \pm 0.41^{\mathrm{dA}}$ \\
\hline & CE0 & $3.31 \pm 0.28^{\mathrm{dE}}$ & $4.56 \pm 0.30^{\mathrm{d} D}$ & $6.62 \pm 0.42^{\mathrm{cC}}$ & $7.05 \pm 0.59^{\mathrm{dBC}}$ & $7.44 \pm 0.34^{\mathrm{dAB}}$ & $7.68 \pm 0.78^{\mathrm{eA}}$ \\
\hline & CE25 & $3.58 \pm 0.49^{\mathrm{dD}}$ & $4.95 \pm 0.58^{\mathrm{dC}}$ & $6.70 \pm 0.48^{\mathrm{cB}}$ & $6.87 \pm 0.41^{\mathbb{A B}}$ & $7.52 \pm 0.57^{\mathrm{dA}}$ & $7.83 \pm 0.42^{\mathrm{eA}}$ \\
\hline & CE50 & $4.55 \pm 0.53^{\mathrm{cE}}$ & $5.56 \pm 0.82^{2 D}$ & $6.82 \pm 0.38^{\mathrm{cC}}$ & $7.88 \pm 0.69^{\mathrm{CB}}$ & $8.41 \pm 0.94^{c^{B}}$ & $11.12 \pm 0.59^{\mathrm{cA}}$ \\
\hline & CE75 & $6.09 \pm 0.45^{6 \mathrm{D}}$ & $8.32 \pm 0.36^{\mathrm{bC}}$ & $8.54 \pm 0.36^{\mathrm{bC}}$ & $9.54 \pm 0.56^{\mathrm{bB}}$ & $12.20 \pm 0.47^{\mathrm{bA}}$ & $12.42 \pm 0.49^{\mathrm{bA}}$ \\
\hline & CE100 & $6.92 \pm 0.78^{\mathrm{aF}}$ & $9.10 \pm 0.57^{\mathrm{aE}}$ & $10.10 \pm 0.40^{\mathrm{aD}}$ & $11.80 \pm 0.48^{2 \mathrm{C}}$ & $13.24 \pm 0.62^{\mathrm{aB}}$ & $15.13 \pm 0.97^{\mathrm{aA}}$ \\
\hline \multirow{6}{*}{ Adhesiveness } & Control & $0.39 \pm 0.06^{\mathrm{A}}$ & $0.39 \pm 0.06^{\mathrm{A}}$ & $0.38 \pm 0.05^{\mathrm{A}}$ & $0.34 \pm 0.04^{\mathrm{aAB}}$ & $0.31 \pm 0.05^{\mathrm{aB}}$ & $0.28 \pm 0.06^{\mathrm{aB}}$ \\
\hline & CE0 & $0.40 \pm 0.06$ & $0.39 \pm 0.05$ & $0.38 \pm 0.06$ & $0.37 \pm 0.06^{\mathrm{a}}$ & $0.36 \pm 0.03^{\mathrm{a}}$ & $0.33 \pm 0.09^{\mathrm{a}}$ \\
\hline & CE25 & $0.40 \pm 0.04^{\mathrm{A}}$ & $0.38 \pm 0.04^{\mathrm{AB}}$ & $0.36 \pm 0.05^{\mathrm{AB}}$ & $0.36 \pm 0.04^{\mathrm{aAB}}$ & $0.34 \pm 0.04^{\mathrm{aBC}}$ & $0.30 \pm 0.04^{\mathrm{aC}}$ \\
\hline & CE50 & $0.40 \pm 0.04^{\mathrm{A}}$ & $0.40 \pm 0.05^{\mathrm{A}}$ & $0.36 \pm 0.06^{\mathrm{AB}}$ & $0.36 \pm 0.06^{\mathrm{aAB}}$ & $0.33 \pm 0.06^{\mathrm{B}}$ & $0.27 \pm 0.06^{\mathrm{aC}}$ \\
\hline & CE75 & $0.40 \pm 0.04^{\mathrm{A}}$ & $0.39 \pm 0.03^{\mathrm{A}}$ & $0.38 \pm 0.03^{\mathrm{A}}$ & $0.38 \pm 0.03^{\mathrm{aA}}$ & $0.33 \pm 0.04^{a \mathrm{~B}}$ & $0.33 \pm 0.05^{\mathrm{aB}}$ \\
\hline & CE100 & $0.40 \pm 0.05^{\mathrm{A}}$ & $0.40 \pm 0.03^{\mathrm{A}}$ & $0.34 \pm 0.03^{\mathrm{B}}$ & $0.23 \pm 0.05^{\mathrm{bC}}$ & $0.21 \pm 0.04^{\mathrm{bCD}}$ & $0.18 \pm 0.04^{\text {bD }}$ \\
\hline \multirow{6}{*}{ Springiness } & Control & $0.90 \pm 0.00^{\mathrm{bA}}$ & $0.89 \pm 0.01^{\mathrm{bB}}$ & $0.88 \pm 0.00^{\mathrm{bC}}$ & $0.87 \pm 0.01^{\mathrm{aC}}$ & $0.81 \pm 0.01^{\mathrm{bD}}$ & $0.81 \pm 0.01^{\mathrm{bD}}$ \\
\hline & $\mathrm{CE} 0$ & $0.91 \pm 0.01^{\mathrm{aA}}$ & $0.90 \pm 0.02^{\mathrm{abA}}$ & $0.89 \pm 0.00^{\mathrm{aA}}$ & $0.88 \pm 0.01^{\mathrm{aB}}$ & $0.86 \pm 0.02^{\mathrm{aB}}$ & $0.83 \pm 0.01^{\mathrm{CC}}$ \\
\hline & CE25 & $0.90 \pm 0.00^{\mathrm{bAB}}$ & $0.90 \pm 0.01^{\mathrm{aA}}$ & $0.89 \pm 0.01^{\mathrm{B}}$ & $0.87 \pm 0.01^{\mathrm{aC}}$ & $0.80 \pm 0.01^{\mathrm{bcD}}$ & $0.78 \pm 0.02^{\mathrm{CE}}$ \\
\hline & CE50 & $0.90 \pm 0.01^{\mathrm{bA}}$ & $0.89 \pm 0.00^{\mathrm{abB}}$ & $0.88 \pm 0.00^{\mathrm{abB}}$ & $0.84 \pm 0.01^{\mathrm{bC}}$ & $0.80 \pm 0.01^{\mathrm{bcD}}$ & $0.68 \pm 0.01^{\mathrm{dE}}$ \\
\hline & CE75 & $0.89 \pm 0.00^{\mathrm{cA}}$ & $0.89 \pm 0.00^{\mathrm{bA}}$ & $0.88 \pm 0.01^{\mathrm{bB}}$ & $0.81 \pm 0.02^{\mathrm{cC}}$ & $0.79 \pm 0.01^{\mathrm{cD}}$ & $0.52 \pm 0.01^{\mathrm{EE}}$ \\
\hline & CE100 & $0.82 \pm 0.00^{\mathrm{dA}}$ & $0.79 \pm 0.01^{\mathrm{cB}}$ & $0.76 \pm 0.01^{\mathrm{cC}}$ & $0.69 \pm 0.01^{\mathrm{dD}}$ & $0.46 \pm 0.01^{\mathrm{dE}}$ & $0.33 \pm 0.01^{\mathrm{fF}}$ \\
\hline \multirow{6}{*}{ Cohesiveness } & Control & $0.52 \pm 0.02^{\mathrm{aA}}$ & $0.50 \pm 0.07^{\mathrm{aAB}}$ & $0.48 \pm 0.01^{\mathrm{bBC}}$ & $0.47 \pm 0.01^{\mathrm{abC}}$ & $0.46 \pm 0.00^{\mathrm{aC}}$ & $0.43 \pm 0.01^{\mathrm{bD}}$ \\
\hline & CE0 & $0.52 \pm 0.01^{\mathrm{aA}}$ & $0.48 \pm 0.00^{\mathrm{abB}}$ & $0.48 \pm 0.00^{6 \mathrm{~B}}$ & $0.45 \pm 0.01^{\mathrm{bcC}}$ & $0.44 \pm 0.03^{\mathrm{bC}}$ & $0.42 \pm 0.01^{\mathrm{bD}}$ \\
\hline & CE25 & $0.52 \pm 0.01^{\mathrm{aA}}$ & $0.46 \pm 0.01^{\mathrm{bB}}$ & $0.45 \pm 0.00^{\mathrm{cB}}$ & $0.45 \pm 0.04^{b c B C}$ & $0.43 \pm 0.01^{\mathrm{bcc}}$ & $0.40 \pm 0.02^{\mathrm{cD}}$ \\
\hline & CE50 & $0.51 \pm 0.05^{\mathrm{abA}}$ & $0.50 \pm 0.01^{\mathrm{aA}}$ & $0.50 \pm 0.00^{\mathrm{aA}}$ & $0.47 \pm 0.01^{\mathrm{aB}}$ & $0.47 \pm 0.01^{\mathrm{aB}}$ & $0.46 \pm 0.01^{\mathrm{aB}}$ \\
\hline & CE75 & $0.51 \pm 0.02^{\mathrm{abA}}$ & $0.48 \pm 0.01^{\mathrm{abB}}$ & $0.47 \pm 0.02^{\mathrm{bB}}$ & $0.44 \pm 0.00^{\mathrm{cC}}$ & $0.41 \pm 0.02^{\mathrm{cdD}}$ & $0.40 \pm 0.00^{\mathrm{cE}}$ \\
\hline & CE100 & $0.49 \pm 0.01^{\mathrm{bA}}$ & $0.46 \pm 0.02^{\mathrm{bB}}$ & $0.41 \pm 0.01^{\mathrm{dC}}$ & $0.39 \pm 0.01^{\mathrm{dD}}$ & $0.39 \pm 0.03^{\mathrm{d}}$ & $0.37 \pm 0.01^{\mathrm{dE}}$ \\
\hline \multirow{6}{*}{ Gumminess } & Control & $2.92 \pm 0.48^{\mathrm{bC}}$ & $3.02 \pm 0.55^{\mathrm{bC}}$ & $3.88 \pm 0.36^{\mathrm{bB}}$ & $3.80 \pm 0.15^{\mathrm{cB}}$ & $4.09 \pm 0.35^{\mathrm{bAB}}$ & $4.38 \pm 0.20^{\mathrm{cA}}$ \\
\hline & CE0 & $1.71 \pm 0.14^{\mathrm{dC}}$ & $2.18 \pm 0.14^{c^{\mathrm{B}}}$ & $3.17 \pm 0.21^{\mathrm{dA}}$ & $3.18 \pm 0.27^{\mathrm{dA}}$ & $3.28 \pm 0.33^{\mathrm{cA}}$ & $3.26 \pm 0.29^{\mathrm{dA}}$ \\
\hline & CE25 & $1.86 \pm 0.25^{\mathrm{dC}}$ & $2.27 \pm 0.27^{\mathrm{BB}}$ & $3.04 \pm 0.22^{\mathrm{dA}}$ & $3.07 \pm 0.41^{\mathrm{dA}}$ & $3.23 \pm 0.29^{\mathrm{cA}}$ & $3.16 \pm 0.18^{d A}$ \\
\hline & CE50 & $2.32 \pm 0.40^{\mathrm{CE}}$ & $2.78 \pm 0.43^{\mathrm{bD}}$ & $3.38 \pm 0.20^{\mathrm{cC}}$ & $3.72 \pm 0.35^{\mathrm{cBC}}$ & $3.96 \pm 0.48^{6 B}$ & $5.10 \pm 0.35^{\mathrm{bA}}$ \\
\hline & CE75 & $3.09 \pm 0.29^{\mathrm{abC}}$ & $3.99 \pm 0.21^{\mathrm{aB}}$ & $4.02 \pm 0.28^{\mathrm{abB}}$ & $4.16 \pm 0.25^{\mathrm{bB}}$ & $5.04 \pm 0.26^{\mathrm{aA}}$ & $4.91 \pm 0.21^{\mathrm{bA}}$ \\
\hline & CE100 & $3.38 \pm 0.39^{\mathrm{aE}}$ & $4.20 \pm 0.32^{2 \mathrm{D}}$ & $4.14 \pm 0.20^{\mathrm{aD}}$ & $4.65 \pm 0.18^{\mathrm{aC}}$ & $5.21 \pm 0.53^{\mathrm{aB}}$ & $5.67 \pm 0.43^{\mathrm{aA}}$ \\
\hline \multirow{6}{*}{ Chewiness } & Control & $2.62 \pm 0.43^{\mathrm{aB}}$ & $2.69 \pm 0.49^{6 \mathrm{~B}}$ & $3.40 \pm 0.31^{\mathrm{aA}}$ & $3.30 \pm 0.15^{\mathrm{aA}}$ & $3.31 \pm 0.31^{\mathrm{bA}}$ & $3.56 \pm 0.19^{\mathrm{aA}}$ \\
\hline & CE0 & $1.55 \pm 0.12^{\mathrm{cC}}$ & $1.96 \pm 0.15^{\mathrm{cB}^{\mathrm{B}}}$ & $2.83 \pm 0.17^{\mathrm{dA}}$ & $2.78 \pm 0.25^{\mathrm{bA}}$ & $2.84 \pm 0.32^{\mathrm{cA}}$ & $2.70 \pm 0.26^{\mathrm{bA}}$ \\
\hline & CE25 & $1.67 \pm 0.22^{\mathrm{cC}}$ & $2.05 \pm 0.25^{\mathrm{cB}}$ & $2.70 \pm 0.17^{\mathrm{dA}}$ & $2.66 \pm 0.37^{\mathrm{bA}}$ & $2.58 \pm 0.24^{\mathrm{cdA}}$ & $2.47 \pm 0.13^{\mathrm{cA}}$ \\
\hline & CE50 & $2.10 \pm 0.36^{6 \mathrm{D}}$ & $2.48 \pm 0.38^{\mathrm{bC}}$ & $2.99 \pm 0.18^{\mathrm{bcB}}$ & $3.14 \pm 0.27^{\mathrm{aB}}$ & $3.18 \pm 0.37^{\mathrm{bAB}}$ & $3.48 \pm 0.22^{\mathrm{aA}}$ \\
\hline & CE75 & $2.74 \pm 0.27^{\mathrm{aC}}$ & $3.55 \pm 0.18^{\mathrm{aB}}$ & $3.52 \pm 0.23^{\mathrm{aB}}$ & $3.35 \pm 0.18^{\mathrm{aB}}$ & $3.99 \pm 0.24^{\mathrm{aA}}$ & $2.54 \pm 0.13^{\mathrm{bcC}}$ \\
\hline & CE100 & $2.78 \pm 0.32^{a \mathrm{~B}}$ & $3.33 \pm 0.24^{\mathrm{aA}}$ & $3.13 \pm 0.16^{\mathrm{bA}}$ & $3.19 \pm 0.12^{\mathrm{aA}}$ & $2.41 \pm 0.22^{\mathrm{dC}}$ & $1.89 \pm 0.16^{\mathrm{dD}}$ \\
\hline
\end{tabular}

${ }^{1)}$ Control, water $700 \mathrm{~g}$; CE0, water $670 \mathrm{~g}$ +lactic acid bacteria cultured $30 \mathrm{~g}$; CE25, water $670 \mathrm{~g}+$ lactic acid bacteria cultured $22.5 \mathrm{~g}$ +cinnamon extract $7.5 \mathrm{~g}$; CE50, water $670 \mathrm{~g}+$ lactic acid bacteria cultured $15 \mathrm{~g}$ +cinnamon extract $15 \mathrm{~g}$; CE75, water $670 \mathrm{~g}$ +lactic acid bacteria cultured $7.5 \mathrm{~g}$ +cinnamon extract $22.5 \mathrm{~g}$; CE100, water $670 \mathrm{~g}+$ cinnamon extract $30 \mathrm{~g}$.

${ }^{2)}$ All values are mean $\pm \mathrm{SD}$. Mean with different superscript within a column are significantly different $(\mathrm{p}<0.05)$ by Duncan's multiple range test.

3)ace Means Duncan's multiple range test for different addition (column).

${ }^{4) A-F}$ Means Duncan's multiple range test for storage time (row). 
Table 5. Avrami exponent, rate constant and time constant of loaf bread with lactic acid bacteria cultured and cinnamon extract

\begin{tabular}{cccc}
\hline Samples $^{1)}$ & $\begin{array}{c}\text { Avrami exponent } \\
\left.(n)^{2}\right)^{2}\end{array}$ & $\begin{array}{c}\text { Rate constant } \\
\left(\AA^{3}\right)^{3}\end{array}$ & $\begin{array}{c}\text { Time constant } \\
(1 / \AA)\end{array}$ \\
\hline Control & 1.8109 & 0.0127 & 78.74 \\
CE0 & 1.5304 & 0.0307 & 32.57 \\
CE25 & 1.2988 & 0.0263 & 38.02 \\
CE50 & 1.2316 & 0.0096 & 104.17 \\
CE75 & 1.2768 & 0.0296 & 33.78 \\
CE100 & 1.1097 & 0.0147 & 68.03 \\
\hline
\end{tabular}

${ }^{1)}$ Control, water $700 \mathrm{~g}$; CE0, water 670 g+lactic acid bacteria cultured $30 \mathrm{~g}$; CE25, water $670 \mathrm{~g}+$ lactic acid bacteria cultured $22.5 \mathrm{~g}+$ cinnamon extract $7.5 \mathrm{~g}$; CE50, water $670 \mathrm{~g}+$ lactic acid bacteria cultured $15 \mathrm{~g}+$ cinnamon extract $15 \mathrm{~g}$; CE75, water $670 \mathrm{~g}$ +lactic acid bacteria cultured $7.5 \mathrm{~g}+$ cinnamon extract $22.5 \mathrm{~g}$; CE100, water $670 \mathrm{~g}+$ cinnamon extract $30 \mathrm{~g}$.

${ }^{2)}$ Values obtained from slop of plot $\log \left\{-\ln \left(\mathrm{E}_{\mathrm{L}}-\mathrm{E}_{\mathrm{S}}\right) /\left(\mathrm{E}_{\mathrm{L}}-\mathrm{E}_{0}\right)\right\}$ vs $\log \mathrm{t}$

${ }^{3)}$ Values obtained from slop of plot $-\ln \left(\mathrm{E}_{\mathrm{L}}-\mathrm{E}_{1}\right)$ vs time.

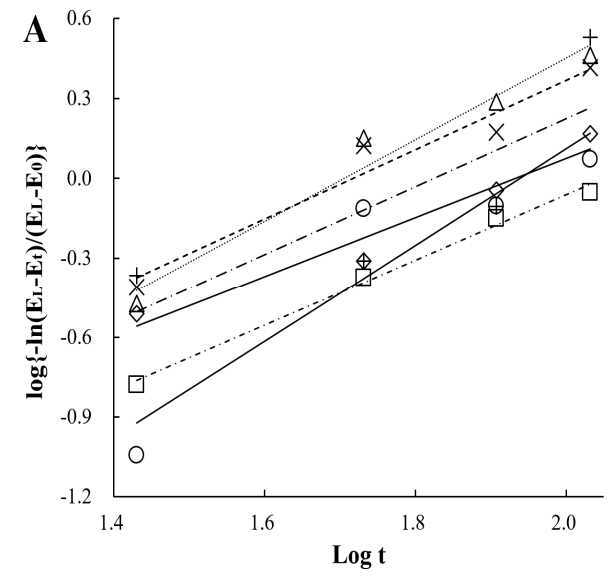

Control $\mathrm{y}=1.8109 \mathrm{x}-3.4214$ $\mathrm{R}^{2}=0.8752$

$\triangle \mathrm{CE0}$ $\mathrm{y}=1.5304 \mathrm{x}-2.5341$ $\mathrm{R}^{2}=0.965$ $\times$ CE25 $\mathrm{y}=1.2988 \mathrm{x}-2.1655$ $\mathrm{R}^{2}=0.951$ $\square$ CE50 $\mathrm{y}=1.2316 \mathrm{x}-2.4632$ $\mathrm{R}^{2}=0.9929$ + CE75 $\mathrm{y}=1.2768 \mathrm{x}-2.2656$ $\mathrm{R}^{2}=0.6626$ $\diamond$ CE100 $\mathrm{y}=1.1097 \mathrm{x}-2.0889$ $\mathrm{R}^{2}=0.9503$

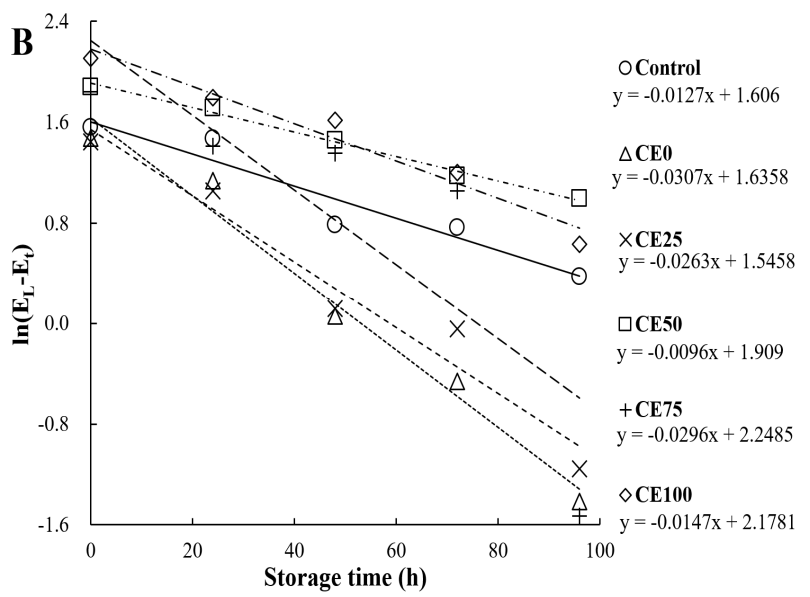

Fig. 1. Plot $\log \left\{-\ln \left(\mathrm{E}_{\mathrm{L}}-\mathrm{E}_{\mathrm{t}}\right) /\left(\mathrm{E}_{\mathrm{L}}-\mathrm{E}_{0}\right)\right\}$ vs $\log t(\mathrm{~A})$ and polt $-\ln \left(\mathrm{E}_{\mathrm{L}}-\mathrm{E}_{\mathrm{t}}\right)$ vs time (B) for loaf bread with lactic acid bacteria cultured and cinnamon extract.

- $\mathrm{O}$-, control (addition of water $700 \mathrm{~g}$ ); - $\triangle$-, CE0 sample (addition of water $670 \mathrm{~g}$ +lactic acid bacteria cultured $30 \mathrm{~g}$ ); - $\mathrm{X}_{-}$, CE25 sample (addition of water $670 \mathrm{~g}+$ lactic acid bacteria cultured $22.5 \mathrm{~g}+$ cinnamon extract $7.5 \mathrm{~g}$ ); - $\square$-, CE50 sample (addition of water $670 \mathrm{~g}+$ lactic acid bacteria cultured $15 \mathrm{~g}+$ cinnamon extract $15 \mathrm{~g}$ ); -+-, CE75 sample (addition of water $670 \mathrm{~g}+$ lactic acid bacteria cultured $7.5 \mathrm{~g}+$ cinnamon extract $22.5 \mathrm{~g}$ ); - $\diamond-$, CE100 sample (addition of water $670 \mathrm{~g}+$ cinnamon extract).
시간 $t$ 를 축으로 나타낸 결과는 Fig. 1과 같다. Avrami 지수 (n)는 결정체가 형성되는 시간과 결정형을 갖는 속도를 복 합적으로 나타내주는 값으로 Avrami 지수 값이 낮으면 노 화를 억제하는 효과적인 물질로 판단하고, 속도상수 $(\AA)$ 의 역수인 시간상수(1/k)는 노화의 진행 속도로써 속도상수의 값이 클수록 노화가 지연되는 효과가 높은 것을 나타낸다 (44-46). 대조구의 Avrmi 지수(n)값은 1.8109이었고, 유산균 배양액과 계피추출물을 첨가한 식빵의 Avrmi 지수(n)는 1.1097-1.5304로 모든 시료에서 대조구보다 낮아 유산균 배양액과 계피추출물은 식빵의 노화를 억제하는 물질로 생각되며, Crowley 등(13)의 연구에서는 젖산균을 첨가한 sourdough wheat bread도 대조구와 비교해서 노화가 느려지 는 것으로 나타났다. 노화 속도를 나타내는 시간상수(1/A)에 서 유산균 배양액과 계피추출물을 $1: 1$ 의 비율로 첨가한 CE50 시료는 104.17로 대조구의 78.74 보다 높았다. 따라서 본 연구에서 유산균 배양액과 계피추출물은 노화를 억제하 는 물질이지만 혼합 비율에 따라서 노화 속도에 차이가 있는 것으로 나타났다.

\section{요 약}

본 연구는 유산균 배양애과 계피추출물 물 대신 첨가하 여 제조한 sourdough bread를 저장하면서 수분, $\mathrm{pH}$, 적정산 도, 색도, 물성 및 노화도의 변화를 측정하여 식빵의 저장성 향상과 노화 지연 효과를 연구하였다. 저장 중 수분함량 변화를 측정한 결과, 모든 시료는 저장기간이 길어질수록 모든 시료는 감소하는 경향을 보였고, $\mathrm{CE} 0$ 시료 식빵이 저장기간 동안 가장 수분함량이 높은 것으로 나타났으며, 수분함량 변화도 가장 적은 것으로 나타났다. 저장 중 $\mathrm{pH}$ 의 변화도 수분함량과 마찬가지로 모든 시료에서 저장기간이 길어질수록 감소하는 경향을 보였고, 저장 초기에는 대조 구와 $\mathrm{CE} 0$ 시료가 높았으나 저장기간이 길어질수록 계피추 출물 첨가량이 높은 CE100 시료가 높은 경향을 보였으며, 저장기간 동안 $\mathrm{CE} 100$ 시료의 $\mathrm{pH}$ 가 가장 변화가 적은 것으 로 나타났다. 저장 중 적정산도는 $\mathrm{pH}$ 의 결과와 반대로 모든 시료에서 저장기간이 길어질수록 증가하는 경향을 보였고, 저장 3 일까지는 대조구와 유산균 배양액을 첨가량이 많은 식빵의 적정산도가 낮았으나 그 이후에는 계피추출물 첨가 량이 많은 식빵에서 낮았으며, 계피추출물 첨가량이 많을 수록 저장기간 동안 적정산도 변화가 가장 적었다. 저장 중 색도의 변화에서 백색도는 저장기간이 길어질수록 감소 하는 경향을 보였고, 적색도는 증가하는 경향을 보였으며, 황색도는 감소하다가 다시 증가하는 경향을 보였다. 저장 중 물성의 변화를 측정한 결과 경도와 점착성은 증가하는 경향을 보였고, 부착성, 탄력성 및 응집성은 감소하는 경향 을 보였으며, 씹힘성은 증가 후 다시 감소하는 경향을 보였 
다. 저장 중 노화도 변화에서 유산균 배양액과 계피추출물 을 첨가한 식빵은 대조구보다 Avrmi 지수(n)의 값이 낮았 고, 시간상수(1/R)에서는 CE0에서 가장 낮았고, CE50 시료 가 가장 높아 노화 지연 효과가 가장 큰 것으로 나타났다. Sourdough bread에서 나타나는 특유의 신맛과 냄새를 억제 하여 전체적인 선호도가 높은 것은 계피추출물을 25-50\% 첨가한 식빵으로 나타난 결과를 종합적으로 살펴보면 유산 균 배양액과 계피추출물을 $1: 1$ 의 비율로 첨가하였을 때 가 장 적합한 것으로 판단된다.

\section{감사의 글}

본 연구는 농림축산식품부 고부가가치식품기술개발사 업의 연구비 지원(111143-2)으로 수행된 결과의 일부로 이 에 감사드립니다.

\section{References}

1. Jung KT, Park BG, Lee MH (2017) Quality characteristics of sourdough bread using fermented fig. Culi Sci Hos Res, 23, 56-65

2. Brandt MJ (2007) Sourdough products for convenient use in baking. Food Microbiol, 24, 161-164

3. Arendt EK, Ryan LAM, Bello FD (2007) Impact of sourdough on the texture of bread. Food Microbiol, 24, 165-174

4. An HL, Lee KS (2009) Study on the quality characteristics of pan bread with sourdough starters from added domestic wheat flours. J East Asian Soc Dietary Life, 19, 996-1008

5. Thiele C, Ganzle MG, Vogel RF (2002) Contrzibution of sourdough lactobacilli, yeast and cereal enzymes to the generation of amino acids in dough relevant for bread flavor. Cereal Chem, 79, 45-51

6. Lopez HW, Duclos V, Coudray C, Krespine V, Feillet-Coudray C, Messager A, Demigne C, Remesy C (2003) Making bread with sourdough improves mineral bioavailability from reconstituted whole wheat flour in rats. Nutr, 19, 524-530

7. De Vuyst L, Gaenzle M (2005) Second international symposium on sourdough: from fundamentals to applications. Trends Food Sci Technol, 16, 2-3

8. Kim YM (2018) Quality characteristics of sourdough bread with apple whole wheat flour sour starter. J Korean Soc Food Sci Nutr, 47, 468-475

9. Hansen A, Schieberle P (2005) Generation of aroma compounds during sourdough fermentation: applied and fundamental aspects. Trends Food Sci Technol, 16, 85-94

10. Gucmen D, Gurbuz O, Kumral AY, Dagdelen AF, Sahin I (2007) The effects of wheat sourdough on glutenin patterns, dough rheology and bread properties. Eur Food Res Technol, 225, 821-830

11. Armero E, Collar C (1996) Antistaling additives, flour type and sourdough process effects on functionality of wheat doughs. J Food Sci, 61, 299-303

12. Rouzaud O, Martinez-Anaya MA (1997) Relationships between biochemical and quality-related characteristics of breads, resulting from the interaction of flour, microbial starter and the type of process. Z Lebensm Unters Forsch A, 204, 321-326

13. Crowley P, Schober T, Clarke CI, Arendt EK (2002) The effect of storage time on textural and crumb grain characteristics of sourdough wheat bread. Eur Food Res Technol, 214, 489-496

14. Meignen B, Onno B, Gelinas P, Infantes M, Guilois S, Cahagnier B (2001) Optimization of sourdough fermentation with Lactobacillus brevis and baker's yeast. Food Microbiol, 18, 239-245

15. Katina K, Heinio RL, Autio K, Poutanen K (2006) Optimization of sourdough process for improved sensory profile and texture of wheat bread. LWT-Food Sci Technol, 39, 1189-1202

16. Mori H, Okada H, Onishi H, Takaki S (2001) Bread making using brewing microorganisms (Part 1). New sour bread starter using brewing microorganisms. J Brew Soc Japan, 96, 282-288

17. Kati K, Kaisa P, Karin A (2004) Influence and interactions of processing conditions and starter culture on formation of acids, volatile compounds and amino acids in wheat sourdoughs. Cereal Chem, 81, 598-610

18. Byun JB, Chang JH, Jeoung GY, Lee JS (2015) Effect of rice flour sourdough fermented with Omija (Schizandra chinensis) extract on quality characeristics of bread. Korean J Food Sci Technol, 47, 704-710

19. Byun JB, Lee JS (2017) Fermentative characteristics of rye sourdough containing Omija extracts. Korean J Food Sci Technol, 49, 168-172

20. Ma EB, Yoon HN, Lee S, Jung HN, Choi OJ (2018) Quality properties of whole wheat flour sourdough bread using sweet persimmon stater. Korean J Food Cook Sci, 34, 263-271

21. Choi JH, Kim E, Lee KS (2016) Quality characteristics of sourdough bread made with kamut sour stater. Culi 
Sci Hos Res, 22, 117-133

22. Lim ES (2016) Effect of the mixed culture of heterofermentative lactic acid bacteria and acid-tolerant yeast on the shelf-life of sourdough. Korean J Microbiol, 52, 471-481

23. Lim ES, Kim YM, Lee EW (2017) Functional evaluation of sourdough containing lactic acid bacteria isolated from sliced radish kimchi. Korean J Microbiol, 53, 180-192

24. Elizabeth TJ, Gassara F, Kouassi AP, Brar SK, Belkacemi K (2017) Spice use in food: properties and benefits. Crit Rev Food Sci Nutr, 57, 1078-1088

25. Gruenwald J, Freder J, Armbruester N (2010) Cinnamon and health. Crit Rev Food Sci Nutr, 50, 822-834

26. Ping H, Zhang G, Ren G (2010) Antidiabetic effects of cinnamon oil in diabetic KK-Ay mice. Food Chem Toxicol, 48, 2344-2349

27. Ho SC, Chang KS, Chang PW (2013) Inhibition of neuroinflammation by cinnamon and its main compenents. Food Chem, 138, 2275-2282

28. Choi HN, Oh HH, Yang HS, Hun CK, Bae IH, Lee JS, Jeong YS, Jeong EJ, Jung HK (2013) Antifungal activity against cheese fungi by lactic acid bacteria isolated from kimchi. Korean J Food Preserv, 20, 727-734

29. Huh CK, Hwang TY (2016) Identification of antifungal substance of Lactobacillus sakei subsp. ALI033 and antifungal activity against Penicillium brevicompactum strain FI02. Prev Nutr Food Sci, 21, 52-56

30. Choi YJ, Jin HY, Yang HS, Lee SC, Huh CK (2016) Quality and storage characteristics of yogurt containing Lacobacillus sakei ALI033 and cinnamon ethanol extract. J Anim Sci Technol, 58, 16-22

31. Huh CK, Shim KH (2017) Quality characteristics of sourdough bread added with lactic acid bacteria culture solution and cinnamon extract. Korean J Food Preserv, 24, 764-770

32. AOAC (1995) Official methods of analysis of AOAC Intl. $16^{\text {th }}$ ed, Association of official analytical Chemists, Arlinton, VA, USA, Method 943.02

33. Armero E, Collar C (1998) Crumb firming kinetics of wheat breads with anti-staling additives. J Cereal Sci, 28, 165-174

34. Torrieri E, Pepe O, Ventorino V, Masi P, Cavella S (2014) Effect of sourdough at different concentrations on quality and shelf life of bread. Food Sci Technol, 56, 508-516

35. Abu-Choush M, Herald TJ, Dowell F, Xie F, Aramouni FM, Madl R (2008) Effect of preservatives addition on the shelf-life extensions and quality of flat bread as determined by near-infrared spectroscopy and texture analysis. Int J Food Sci Technol, 43, 357-364

36. Aplevicz KS, Ogliari PJ, Sant'Anna ES (2013) Influence of fermentation time on characteristics of sourdough bread. Braz J Pharm Sci, 49, 233-239

37. Lappi J, Selinheimo E, Schwab U, Katina K, Lehtinen P, Mykkanen H, Kolehmainen M, Poutanen K (2010) Sourdough fermentation of wholemeal wheat bread increases solubility of arabinoxylan and protein and decreases postprandial glucose and insulin responses. J Cereal Sci, 51, 152-158

38. Bartkiene E, Bartkevics V, Krungleviciute V, Pugajeva I, Zadeike D, Juodeikiene G (2017) Lactic acid bacteria combinations for wheat sourdough preparation and their influence on wheat bread quality and acrylamide formation. J Food Sci, 82, 2371-2378

39. Ryu HY, Bae KH, Kum EJ, Park SJ, Lee BH, Sohn HY (2007) Evaluation for the antimicrobial, antioxidant and antithrombosis activity of natural spices for fresh-cut yam. J Life Sci, 17, 652-657

40. Song JH, Lim JA, Lee JH (2014) Quality and antioxidant properties of cookies supplemented with cinnamon powder. J Korean Soc Food Sci Nutr, 43, 1457-1461

41. Park JY, Joo JI, Kim JM (2017) Changes in the quality changes of bread added with acorn the storage periods. J East Asian Soc Diet Life, 27, 529-539

42. Kang EY, Yang YH, Oh SH, Lee JH, Chang KS, Kim MK, Cho HY, Kim MR (2006) Storage quality characteristics of milk bread added with $\beta$-glucan from Agrobacterium spp. R259 KCTC 10197BP. J Korean Soc Food Sci Nutr, 35, 613-621

43. Fagundes GA, Rocha M, Salas-Mellado MM (2018) Improvement of protein content and effect on technological properties of wheat bread with the addition by cobia (Rachycentron canadum). Food Res, 2, 221-227

44. Song KY, O H, Zhang Y, Joung KY, Kim YS (2016) Effects of pumpkin (Cucurbita moschata Duch.) leaf powder on quality characteristics, antioxidant activities, and retarding retrogradation by shelf-life of Sulgidduck (rice cake). J Korean Soc Food Sci Nutr, 45, 1792-1798

45. Joung KY, Song KY, O H, Zhang Y, Shin SY, Kim YS (2017) Study on the quality characteristics and retarding retrogradation of pound cakes containing teff (Eragrostis tef) flour. J East Asian Soc Diet Life, 27, 41-49

46. Kim SS, Chung HY (2010) Retarding retrogradation of Korean rice cakes (Karaedduck) with a mixture of trehalose and modified starch analyzed by Avrami kinetics. Korean J Food Nutr, 23, 39-44 